\title{
Survey of protozoan vector-borne diseases in dogs from Atlantic Rainforest fragment around Billings Dam, São Paulo, Brazil
}

\author{
Roberta Carvalho de Freitas e Azevedo ${ }^{1}$ (D) Giovanna Stefani Nosberto Castelli ${ }^{1}$ (D \\ Ryan Emiliano da Silva ${ }^{2}$ Jaciara de Oliveira Jorge Costa ${ }^{2}$ (D) Renata Tonhosolo ${ }^{3}$ (D) \\ Eduardo Alberto Reis ${ }^{1}$ Jonas Moraes Filho ${ }^{1}$ Arlei Marcili ${ }^{1,2^{*}}$ (D)
}

\author{
${ }^{1}$ Programa de Mestrado em Medicina e Bem-estar Animal, Universidade Santo Amaro (UNISA), 04829-300, São Paulo, SP, Brasil. E-mail: \\ amarcili@prof.unisa.br. .Corresponding author. \\ ${ }^{2}$ Departamento de Medicina Veterinária Preventiva e Saúde Animal, Universidade de São Paulo (USP), São Paulo, SP, Brasil. \\ ${ }^{3}$ Faculdade de Medicina, Universidade Santo Amaro (UNISA), São Paulo, SP, Brasil.
}

\begin{abstract}
Vector-borne diseases are currently one of the biggest public health concerns worldwide. Dogs, being the closest companion animals to humans, are considered the main reservoir of some of these diseases in the urban environment. Therefore, the study of the disease behavior in dogs can help to understand the disease affecting human health. Serological and molecular diagnoses of Babesia vogeli, Rangelia vitalli, Leishmania infantum, and other trypanosomatids, were performed by immunochromatographic and PCR assays, respectively, on dogs in a dog shelter located in an Atlantic Forest fragment near the Billings Dam, São Bernardo do Campo, São Paulo-Brazil. Our molecular diagnostic results showed a high prevalence of Babesia vogeli, at 20.9\% (17/81). No other protozoan was detected in any of the tests. Determining the prevalence of major vector-borne diseases is essential to establish preventive and control measures for zoonotic diseases in animals kept in shelters, in order to minimize the impact of vector-borne diseases on animal health.
\end{abstract}

Key words: Rhipicephalus, serology, molecular diagnosis, Phlebotomine, ticks.

Levantamento de protozoários transmitidos por vetores em cães de um fragmento de Mata Atlântica nos arredores da Barragem Billings, São Paulo, Brasil

RESUMO: As doenças transmitidas por vetores são atualmente um dos maiores problemas de saúde pública. Os cães, sendo os animais de companhia mais próximos dos seres humanos, são considerados os principais reservatórios de algumas dessas doenças no ambiente urbano, $e$ o estudo de seu comportamento em cães ajuda a entender a doença como um todo na saúde humana. Diagnósticos sorológicos e moleculares de Babesia vogeli, Rangelia vitalli, Leishmania infantum e outros tripanossomatídeos, em um abrigo para cães localizado em um fragmento da Mata Atlântica próximo à Barragem Billings, São Bernardo do Campo, São Paulo, Brasil. Foram realizadas sorologias e diagnósticos moleculares, no ensaio de PCR foram utilizados marcadores moleculares de oligonucleotídeos especificos para alguns protozoários de importância na saúde animal, como Babesia vogeli, Rangelia vitalli, Leishmania infantum e outros tripanossomatideos. Nossos resultados de diagnóstico molecular mostraram uma alta prevalência de 20,9\% (17/81) de Babesia vogeli. Nenhum outro protozoário foi detectado em nenhum dos testes. A determinação da prevalência das principais doenças transmitidas por vetores é essencial para estabelecer medidas preventivas e de controle de doenças zoonóticas em animais mantidos em abrigos. Essas medidas devem ser propostas para minimizar o impacto de doenças transmitidas por vetores na saúde animal.

Palavras-chave: Rhipicephalus, sorologia, diagnóstico molecular, flebotomíneos, carrapatos.

\section{INTRODUCTION}

Vector-borne diseases are one of the biggest public health problems (DANTAS-TORRES, 2008; MAGGI et al., 2019). Dogs, being the closest companion animals to humans, are considered the main reservoir of some of these diseases in the urban environment, and studying the behavior of the disease in dogs can help in our understanding of the disease as a whole and of how it integrates within human health (DANTAS-TORRES, 2008; DANTAS-TORRES et al., 2014).
Visceral leishmaniosis, caused by Leishmania infantum, is now considered one of the most serious vector-borne diseases. In Brazil, it is responsible for $90 \%$ of all human and canine (PAHO, 2019). Lutzomyia longipalpis is the main vector, which is widely distributed (KRAUSPENHAR et al., 2003; MONGRUEL et. al., 2018), but other species of this genus are also considered vectors (WALKER et al., 2000; MORAES-FILHO et al., 2011; DANTASTORRES et al., 2019).

Canine babesiosis is a hemolytic disease that, in Brazil, is caused by Babesia vogeli, in 
which all clinical signs of the disease are caused by erythrocyte lysis (SOARES et al., 2018; DANTASTORRES et al., 2019). It is transmitted by the tick Rhipicephalus sanguineus sensu lato, which has a cosmopolitan distribution, nesting behavior, and easily adapts to changes in temperature and humidity (WALKER et al., 2000; MORAES-FILHO et al., 2011; DANTAS-TORRES et al., 2019).

Rangelia vitalli, the causative agent of canine rangeliosis, is a protozoan piroplasma that infects erythrocytes, leukocytes, and endothelial cells in dogs (CARINE et al., 1914; FIGHERA et al., 2010; MONGRUEL, 2018). It is more common in wild canids because its unique vector, the tick Amblyomma aureolatum, is exclusively found in areas of the Atlantic rainforest where the temperature and humidity conditions are favorable for its development (SOARES et al., 2018; DANTAS-TORRES et al., 2019).

In this study, we performed serological and molecular diagnoses of some protozoans with importance to health that are transmitted by different arthropods, such as Babesia vogeli, Rangelia vitalli, and Leishmania infantum, in a dog shelter located in an Atlantic Forest fragment in the influential area of Billings Dam in the Riacho Grande district, São Bernardo do Campo, São Paulo-Brazil.

\section{MATERIALS AND METHODS}

Geographical area, study population, and sample collection

This study was conducted in a private shelter located in the Riacho Grande district of the city of São Bernardo do Campo in the metropolitan region of São Paulo, located at $23^{\circ} 48^{\prime} 11.2^{\prime \prime} \mathrm{S}$ and $46^{\circ} 32^{\prime}$ $07.6^{\prime \prime} \mathrm{W}$ (Figure 1). The study area is an Atlantic Forest fragmentation close to the Billings Dam. The kennels are rustic, made of wood, and the area for dogs is surrounded by the native Atlantic Rainforest of the region. Dogs in the shelter were mixed-breed animals that had been abandoned nearby, dogs that were born in the shelter from pregnant bitches, dogs that had been adopted more than once and returned due to lack of adaptation to the adopted home, and even purebred species that were part of clandestine kennels or were abandoned because they were born with some deformity or disability. It was not possible to obtain parameters to measure the age of the dogs.

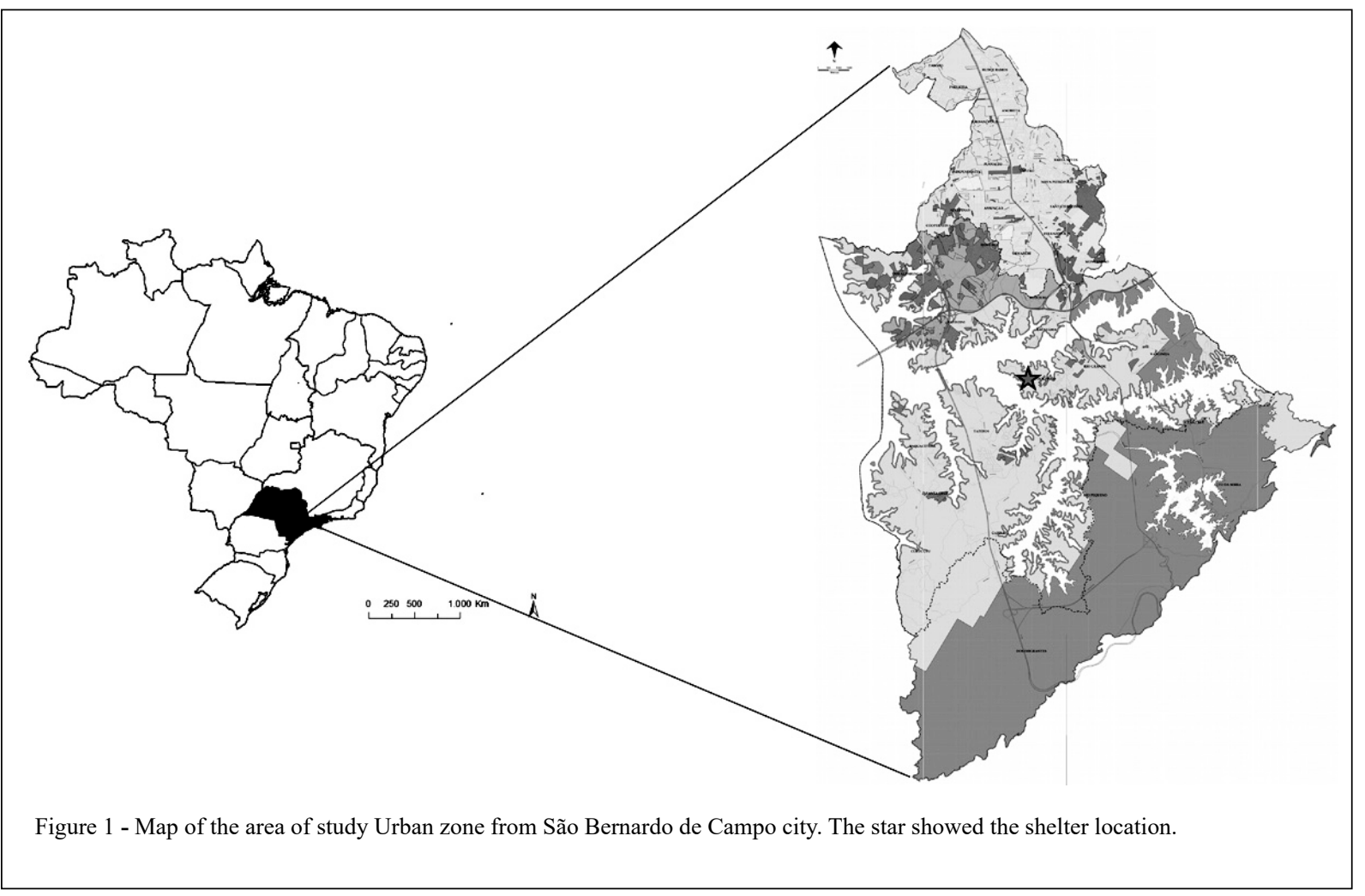

Ciência Rural, v.50, n.9, 2020. 
Peripheral whole blood was collected from all 81 dogs that lived in the shelter on January 15, 2019. All dogs were inspected for the presence of ectoparasites and samples were collected.

In dogs that tested positive for serological and molecular markers of disease, fine needle aspiration of the popliteal lymph nodes was performed to isolate the parasite.

\section{Serological screening}

Serological screening was performed on peripheral whole blood immediately after collection by immunochromatographic assay, using the DPP ${ }^{\odot}$ Rapid Diagnostic Kit for Canine Leishmaniosis (Biomanguinhos/Fiocruz) for the detection of K9/K26/K39-reactive antibodies, according to manufacturer's instructions.

\section{DNA extraction}

For DNA extraction, the commercial PureLink Genomic DNA Mini Kit (Invitrogen) was used according to the manufacturer's instructions.

\section{Molecular markers for diagnosis}

For the specific molecular diagnosis of Leishmania infantum, PCR was performed using L-like Cathepsin genes (SILVA et al., 2019) and ribosomal internal transcribed spacer (ITS) (SCHONIAN et al., 2003) as targets.

For detection of other trypanosomatid species, the V7V8 region of SSU rDNA was used, as this is considered the trypanosomatid barcode (MAIA DA SILVA et al., 2004). The characterization of isolates was performed by sequencing SSU rDNA and gGAPDH (MARCILI et al., 2014).

For Babesia vogeli and Rangelia vitalli, real-time PCR was performed using the sense hsp70-F and antisense hsp70-R primers (PAULINO et al., 2018), and sense Rv751-770 and antisense Rv930911 primers (SOARES et al., 2014), respectively.

\section{Isolation and culture of Leishmania parasites}

For dogs positive by serological and/ or molecular examination, parasite isolation was performed by fine needle aspiration of popliteal lymph nodes (MARCILI et al., 2014). Samples were inoculated into tubes of biphasic medium consisting of BAB (blood agar base, $15 \%$ rabbit blood) as the solid phase and LIT or RPMI medium, containing fetal bovine serum and antibiotics, as the liquid phase.

\section{RESULTS}

The 81 samples were submitted for Leishmania infantum serology by the DPP ${ }^{\odot}$ Rapid
Test distributed by the Brazilian Ministry of Health, and $2.46 \%(2 / 81)$ were positive.

Molecular tests for the trypanosomatid barcode region (V7V8 SSU rDNA) and the gGAPDH gene were negative for all samples. Specific molecular markers for the diagnosis of the Leishmania genus (ITS1 SSU rDNA) and L. infantum species (cathepsin L-like) were also negative for all samples tested.

Additionally, fine needle aspiration of the popliteal lymph nodes in dogs that had a positive reaction to the DPP $C$ test was performed to attempt to isolate parasites. All cultures were negative for trypanosomatid parasites. The molecular diagnosis of Rangelia vitalli was also negative for all samples tested. A total of $20.9 \%$ (17/81) of the samples were positive for Babesia vogeli. No ectoparasites were found in the examined dogs.

\section{DISCUSSION}

In the present study, $20.9 \%$ of dogs were positive for Babesia vogeli, which is much higher than previous studies conducted in São Paulo and other locations in the Southeast region of Brazil (SILVA et al., 2014; O’DWYER et al., 2009; MONGRUEL et al., 2018). It is known that high canine population density favors both an increase in the number of $R$. sanguineus ticks and their permanence in the environment, as well as pathogen circulation in the population. A study conducted in a dog shelter on Rickettsia rickettsii (PACHECO et al., 2011) demonstrated an increase in both the vectors and agent in the studied population, corroborating the results obtained in this study. However, during sample collection the dogs did not have a tick infestation.

Vector-borne diseases are important in human and animal health worldwide, with cycles involving vertebrates, invertebrates, and their interaction with the environment concerning different levels of anthropic action (ALBERIGI et al., 2019). The São Bernardo do Campo municipality is a predominant region of the Atlantic Forest fragments (SÃO BERNARDO DO CAMPO, 2019).

The Atlantic Rainforest has climatic conditions favorable for the development of Amblyomma spp. and phlebotomine (PINTER et al., 2004; SCINACHI et al., 2017); however, positive results were observed only for parasites of the genus Babesia, which is transmitted by ticks of the species $R$. sanguineus that are nidicolous and closely associated with canines in urban areas (GALAY et al., 2018).

In forested areas, adult $A$. aureolatum ticks feed on wild carnivores (GUGLIEMONE et al., 2003), 
whereas in rural areas near forests, these ticks feed on domestic canines, enabling the transfer of these ectoparasites from dogs to humans (GUGLIEMONE et al., 2003; PINTER et al., 2004). A. aureolatum is the only species capable of transmitting $R$. vitalli, thus all clinical cases are related to an infestation of this tick (SOARES et al., 2018; SILVA et al., 2019). All dogs sampled in this study were kept in enclosures without access to the woods around the shelter, which corroborates the negative results for $R$. vitalli.

Positive results of serological tests for Leishmania may result from cross-reactions with other pathogens, most commonly with other trypanosomes, such as Trypanosoma caninum (ALVES et al., 2012), and leishmania vaccines (SOLANO-GALEGO et al., 2017; MARCONDES et al., 2013). This may account for the positive serological tests in this study, as the parasitological diagnosis was negative for serologically positive dogs. In addition, the molecular diagnosis was negative for all samples based on cathepsin L-like and ITS SSU rDNA markers. Despite the low parasitemia presented in Leishmania infantum infections, the use of the whole blood instead of the poplitel lymph node samples for molecular diagnosis is based to the high sensitivity and specificity of the marker based on Catepsin L-like.

The canine population in the city of São Paulo was estimated at 2,507,401 in 2012, with a human:dog ratio of 4.34 , and a higher concentration of dogs in urban areas than rural areas of the municipality (CANATTO et al., 2012). The proportion of dogs adopted (73.9\%) was significantly higher than that of dogs purchased $(26.1 \%)$, and the frequency of dog adoption is correlated with the frequency of households with a dog and greater levels of social exclusion (CANATTO et al., 2012). In this context, dog shelters play an important role in dog care and the adoption process.

Sanitation guidelines for animals kept in shelters should be proposed to minimize the impact of vector-borne diseases on animal health, as well as for the prevention and control of zoonotic diseases.

\section{CONCLUSION}

This study showed that Babesia vogeli is highly prevalent in dogs from the Atlantic Rainforest fragment around Billings Dam, São Paulo-Brazil. These results also emphasized the need to test for multiple vector-borne diseases in dogs suspected of infection, to facilitate appropriate treatment and to promote the adoption of animals abandoned and kept in shelters.

\section{ACKNOWLEDGEMENTS}

The authors thank all shelter's professionals of accepted to collaborate in this study and Conselho Nacional de Desenvolvimento Científico e Tecnológico - $\mathrm{CNPq}$ [process number 303288/2015-9 and 302145/2018-4], Fundação de Amparo a Pesquisa do Estado de São Paulo [process number 2015/25592-3] and was financed in part by the Coordenação de Aperfeiçoamento de Pessoal de Nível Superior (CAPES), Brasil - Finance code 001.

\section{BIOETHICS AND BIOSSECURITY COMMITTEE APPROVAL}

This work was analyzed and approved by the research ethics committee on the use of animals at the Universidade Santo Amaro (UNISA) (authorization no. 19/2018).

\section{DECLARATION OF CONFLICTS OF INTERESTS}

The authors declare no potential conflicts of interest with respect to the research, authorship, and/or publication of this article.

\section{AUTHORS' CONTRIBUTIONS}

The authors contributed equally to the manuscript.

\section{REFERENCES}

ALBERIGI, B, et al. Serological evidence of canine arthropodborne infections in an ecotone area of a natural reserve at the Pantanal, Brazil. Braz J Vet Med. v.41. 2019. Available from: $<$ http://rbmv.org/index.php/BJVM/article/view/1037>. Accessed: Oct. 12, 2019. doi: 10.29374/2527-2179.bjvm103719.

ALVES, A.S, et al. Evaluation of serological cross-reactivity between canine visceral leishmaniasis and natural infection by Trypanosoma caninum. Res Vet Sci. v.93 (3) 1329-1333. 2012. Available from: <https://www.sciencedirect.com/science/article/ abs/pii/S0034528812002147?via\%3Dihub>. Accessed: Jul. 12, 2019. doi: 10.1016/j.rvsc.2012.07.006

CANATTO, B.D, et al. Demographic characterization of supervised dog and cat populations in São Paulo city, Brazil. Arq. Bras. Med. Vet. Zootec. v.64 (6) 1414-1523. 2012. Available from: <http://www.scielo.br/scielo.php?pid=S0102$09352012000600017 \&$ script $=$ sci arttext\&tlng $=$ pt $>$. Accessed: Oct. 12,2019

CARINE, A, et al. Sobre a moléstia dos cães, chamada Nambi-Uvú e seu parasita Rangélia vitalli. Anais Paul. Med. Cir. v.3. 65-71. 1914.

DANTAS TORRES, F. et al. Dogs, cats, parasites, and humans in Brazil: opening the black box. Parasit Vectors. v.7, 22. 2014. Available from: <https://link.springer.com/ article/10.1186/1756-3305-7-22>. Accessed: Feb. 12, 2019. doi: $10.1186 / 1756-3305-7-22$. 
DANTAS-TORRES, F, et al. Ticks (Ixodida: Argasidae, Ixodidae) of Brazil: Uptaded species checklist and taxonomic keys. Ticks Tick Borne Dis. v.10 (6). 2019. Avalable from: <https://www. sciencedirect.com/science/article/abs/pii/S1877959X18304989>. Accessed: Nov. 12, 2019. doi: 10.1016/j.ttbdis.2019.06.012.

DANTAS-TORRES, F. Canine vector-borne diseases in Brazil Parasit Vectors. 2008; 1,25. Available from: $<$ https://link.springer. com/article/10.1186/1756-3305-1-25>. Accessed: Mar. 12, 21019. doi: $10.1186 / 1756-3305-1-25$.

FIGHERA, R. A., et al. Pathogenesis, clinical, hematological, and pathological aspects of Rangelia vitalli infection in 35 dogs (1985-2009). Pesq Vet Bras. v.30, 974-987. 2010. Available from: <http://www.scielo.br/scielo.php?pid=S0100736X2010001100012\&script $=$ sci_arttext $>$. Accessed: Oct. 12, 2019. doi: 10.1590/S0100-736X2010001100012.

GALAY, R.L, et al. Molecular detection of tick-borne pathogens in canine population and Rhipicephalus sanguineus (sensu lato) ticks from southern Metro Manila and Laguna, Philippines. Parasit Vectors. v.11(643). 2018. Available from: < https://link.springer. com/article/10.1186/s13071-018-3192-y>. Accessed: Mar. 2019. doi: 10.1186/s13071-018-3192-y.

GALVIS-OVALLOS, F, et al. Canine visceral leishmaniasis in the metropolitan área of São Paulo: Pintomyia fischeri as potential vector of Leishmania infantum. Parasite. v.24 (2)110.2017. Available from: <https://www.ncbi.nlm.nih.gov/pmc/ articles/PMC5780806/>. Accessed: Feb. 12, 2019. doi: 10.1051/ parasite/2017002.

GUGLIELMONE, A.A, et al. Amblyomma aureolatum (Pallas, 1972) and Amblyomma ovale Koch, 1844 (Acari: Ixodidae): hosts, distribution and 16S rDNA sequences. Vet Parasitol. v.113 (3-4) 273-288. 2003. Available from: <https://www.sciencedirect.com/ science/article/abs/pii/S0304401703000839>. Accessed: Feb. 2019. doi: 10.1016/S0304-4017(03)00083-9.

KRAUSPENHAR, C, et al. Anemia hemolítica em cães associada a protozoários. Medvep - Rev. Cient. Med. Vet. Pequenos Animais de Estimaçao. v.1, 273-281. 2003. Available from: <http://www. rafaelfighera.com.br/wp-content/uploads/2014/06/rafaelfighera anemia-hemolitica-em-caes-associada-a-protozoarios.pdf $>$. Accessed: Jul. 12, 2019.

LAISON, R, et al. Lutzomyia longipalpis and the ecoepidemiology of American visceral leishmaniasis, with particular reference to Brazil: a review. Mem Inst Oswaldo Cruz. v.100 (8) 811-827. 2005. Available from: <http://www.scielo.br/scielo. php?pid $=$ S0074-02762005000800001\&script $=$ sci_arttext $>$. Accessed: Feb. 2019. doi: 10.1590/S0074-02762005000800001.

LAURENTI, M.D, et al. Comparative evaluation of the DPP $\left({ }^{\circledR}\right)$ CVL rapid test for canine serodiagnosis in area of visceral leishmaniasis. Vet. Parasitol. v.3 (4) 444-450. 2014. Available from: $\quad<$ https://www.sciencedirect.com/science/article/abs/pii/ S0304401714004877>. Accessed: Feb. 12, 2019. doi: 10.1016/j. vetpar.2014.09.002.

LAVITSCHKA, C.O, et al. Ocurrences of phlebotomine sand flies (Diptera: Psychodidae) potentially associated with leishmaniasis transmission in uban parks in the City of São Paulo, Brazil. J Am Mosq Control Assoc. v.34 (2) 151-153. 2018 Available from: $<$ https://www.mosquito-jamca.org/doi/full/10.2987/18-6735.1>. Accessed: Apr. 12, 2019. doi: 10.2987/18-6735.1.
MAGGI, R.G, et al. A review on the occurrence of companion vector-borne diseases in pet animals in Latin America. Parasit Vectors. v.12, 145. 2019. Available from: <https:// parasitesandvectors.biomedcentral.com/articles/10.1186/s13071019-3407-x>. Accessed: Oct. 12, 2019. doi: 10.1186/s13071-0193407-x.

MAIA DA SILVA, F, et al. Phylogeny, taxonomy and grouping of Trypanosoma rangeli isolates from man, triatomines and sylvatic mammals from widespread geographical origin based on SSU and ITS ribosomal sequences. Parasitology. v.129 (5) 549-561. 2004. Available from: <https://www.cambridge.org/ core/journals/parasitology/article/phylogeny-taxonomy-andgrouping-of-trypanosoma-rangeli-isolates-from-man-triatominesand-sylvatic-mammals-from-widespread-geographical-originbased-on-ssu-and-its-ribosomal-sequences/6BB919103BE55FE 6F640B3BB9417095C $>$. Accessed: Feb. 12, 2019. doi: 10.1017/ S0031182004005931.

MARCILI, A, et al. Phylogenetics relationships of Leishmania species based on trypanosomatid barcode (SSU rDNA) and gGAPDH genes: taxonomic revision of Leishmania (l.) infantum chagasi in South America. Infec Genect Evol. v.25 44-51. 2014. Available from: <https://www.sciencedirect.com/science/ article/pii/S1567134814001233>. Accessed: Feb. 12, 2019. doi: 10.1016/j.meegid.2014.04.001.

MARCONDES, M, et al. Longitudinal analysis of serological tests officially adopted by the Braziian Ministry of Healhy for the diagnosis of canine visceral leishmaniasis in dogs vaccinated with Leishmune $^{\circledR}$. Vet parasitol. v.197 (3-4) 649-652. 2013. Available from: $\quad<$ https://www.sciencedirect.com/science/article/abs/pii/ S0304401713003877>. Accessed: Jul. 12, 2019. doi: 10.1016/j. vetpar.2013.07.013.

MONGRUEL, A.C.B, et al. Molecular detection of vector borne pathogens in anemic and thrombocytopenic dogs in southern Brazil. Rev. Bras. de Parasitol Vet. v.27 (4), 505-513. 2018. Available from: <http://www.scielo.br/scielo.php?pid=S198429612018005013103\&script $=$ sci arttext $>$. Accessed: Feb. 12, 2019. doi: 10.1590/s1984-296120180069.

MORAES-FILHO, J, et al. Genetic analysis of ticks belonging to the Rhipicephalus sanguineus group in Latin America. Acta Tropica. v.117(1) 51-55. 2011. Available from: <https://www. sciencedirect.com/science/article/abs/pii/S0001706X10002391>. Accessed: Oct. 12 2019. doi: 10.1016/j.actatropica.2010.09.006

O’DWYER, L.H, et al. Infecção por Babesia spp. em cães de áreas rurais do estado de São Paulo, Brasil. Rev Bras Parasitol Vet. v.18 (2) 23-26. 2009. Available from: <http://www.scielo.br/ scielo.php?script $=$ sci arttext\&pid $=\mathrm{S} 1984-29612009000200005>$. Accessed: Oct. 2019. doi: 10.4322/rbpv.01802005

PACHECO, R.C, et al. Rickettsial infections of dogs, horses and ticks in Juiz de Fora, southeastern Brazil, and isolation of Rickettsia rickettsi from Rhipicephalus saguineus ticks. Med Vet Entomol. v.25 (2) 148-155. 2011. Available from: <https://onlinelibrary. wiley.com/doi/abs/10.1111/j.1365-2915.2010.00915.x>. Accessed: Jul. 12, 2019. doi: 10.1111/j.1365-2915.2010.00915.x

PAHO (Pan American Health Organization). Leishmaniasis: Epidemiological report of the Americas. n.7, Washington. 2019 PAHO/WHO. Available from: <www.paho.org/leishmaniasis>. Accessed: Oct. 12, 2019. 
PAULINO, P.G, et al. Molecular epidemiology of Babesia vogeli in dogs from the southeastern region of Rio de Janeiro, Brazil. Vet Parasitol Reg Stud Reports. v.13, 160-165. 2018. Available from: <https://www.sciencedirect.com/science/article/ pii/S2405939018300558>. Accessed: Jul. 2019. doi: 10.1016/j. vprsr.2018.06.004

PINTER, A, et al. Study of the seasonal dynamics, life circle, and host specificity of Amblyomma aureolatum (Acari: Ixodidae). J Med Entomol. v.41 (3) 324-332. 2004. Available from: <https:// academic.oup.com/jme/article-abstract/41/3/324/916240>. Accessed: Jul. 2019. doi: 10.1603/0022-2585-41.3.324.

SÃO BERNARDO DO CAMPO. Caracterização Ambiental de São Bernardo do campo: Uma breve caracterização dos aspectos ambientais do município de São Bernardo do Campo, Estado de São Paulo. $1^{\text {a }}$ Ed. Secretaria de Meio Ambiente e Proteção Ambiental. Prefeitura de São Bernardo do Campo. 2019; (32p). Avaiable from: $<$ http://www.saobernardo.sp.gov.br/documents/895750/896331/ caracterizacao_ambiental_base_20190404.pdf/15be39ea-bbdd954a-b804-c4fd770545a41>. Accessed: Oct. 12, 2019.

SCINACHI, C.E, et al. Association of the occurrence of Brazilian spotted fever and Atlantic rain forest fragmentation in the São Paulo metropolitan region, Brazil. Acta Trop. v.166, 225-233. 2017. Available from: <https://www.sciencedirect.com/science/ article/pii/S0001706X16306465>. Accessed: Oct. 12, 2019. doi: 10.1016/j.actatropica.2016.11.025.

SHCÖNIAN, G, et al. PCR diagnosis and characterization of Leishmania in local and imported clinical samples. Diagn Microbiol Infect Dis. v.47 349-358. 2003. Available from: <https://www. sciencedirect.com/science/article/abs/pii/S0732889303000932 . Accessed: Feb. 12, 2019. doi: 10.1016/S0732-8893(03)00093-2

SILVA, B.R.F, et al. Rangelia-Vitalli infection in a dog from São Paulo city, Brazil; case report. Braz J Vet Res Anim Sci. v.56 (3). 2019. Available from: <https://www.revistas.usp.br/bjvras/article/ view/150791>. Accessed: Oct. 12, 2019. doi: 10.11606/issn.16784456.bjvras.2019.150791.

SILVA, M.C.A, et al. Hemoparasitoses em cães domésticos naturalmente infectados, provenientes das zonas urbana e rural do município de Abadia dos Dourados, Minas Gerais, Brasil. Biosci J. v.30 (5) 892-900. 2014. Available from: <http://www.seer.ufu.br/index.php/ biosciencejournal/article/view/19608>. Accessed: Oct. 12, 2019.

SILVA, R.E, et al. Exploring Leishmania infantum as a new molecular marker for phylogenetic relationships and visceral leishmaniasis diagnosis. BMC infect Dis. v.19 (895). 2019. Available from: $<$ https://link.springer.com/article/10.1186/s12879-019-4463-8>. Accessed: Oct. 12, 2019. doi: /10.1186/s12879-019-4463-8.

SOARES, J.F, et al. Evaluations of the vector competence of six ixodid tick species for Rangelia vitalli (Apicomplexa, Piroplasmorida), the agent of canine rangeliosis. Ticks Tick Borne dis. v.9 (5) 1221-1234. 2018. Available from: <https://www. sciencedirect.com/science/article/pii/S1877959X18301134>. Accessed: Oct. 12, 2019. doi: 10.1016/j.ttbdis.2018.05.004

SOARES, J.F, et al. Natural infection of the wild canid, Cerdocyon thous, with the piroplasmid Rangelia Vitalli in Brazil. Vet Parasitol. v.202, 156-163. 2014. Available from: $<$ https://www.sciencedirect. com/science/article/pii/S0304401714001575 $\geq$. Accessed: Oct. 12, 2019. doi: 10.1016/j.vetpar.2014.02.058.

SOLANO-GALLEGO, et al. Diagnostic challenges in the era of canine Leishamania infantum vaccines. Trends Parasitol. v.9, 706-717. 2017. Available from: <https://www.cell.com/trends/ parasitology/fulltext/S1471-4922(17)30153-8?_returnURL=http s\%3A\%2F\%2Flinkinghub.elsevier.com $\% 2$ Fretrieve $\% 2 \mathrm{Fpii} \% 2 \mathrm{~F}$ S1471492217301538\%3Fshowall\%3Dtrue>. Accessed: Oct. 12, 2019. doi: 10.1016/j.pt.2017.06.004.

WALKER, J.B, et al. The Genus Rhipicephalus (Acari, Ixodidae): A guide to the brown ticks of the world. Trop Anim Health Prod. v.32, 417-418. 2000 